\title{
One Belt One Road Initiative: New Route on China's Change of Course to Growth
}

\author{
Cem Nalbantoglu \\ Department of Chinese Language, Chongqing University of Posts and Telecommunications, Chongqing, China \\ Email: cemnalbantoglu@yandex.com
}

How to cite this paper: Nalbantoglu, C. (2017) One Belt One Road Initiative: New Route on China's Change of Course to Growth. Open Journal of Social Sciences, $\mathbf{5}$, 87-99.

http://dx.doi.org/10.4236/jss.2017.51007

Received: December 20, 2016

Accepted: January 10, 2017

Published: January 13, 2017

Copyright $\odot 2017$ by author and Scientific Research Publishing Inc. This work is licensed under the Creative Commons Attribution International License (CC BY 4.0).

http://creativecommons.org/licenses/by/4.0/

\begin{abstract}
China's One Belt One Road Initiative (OBOR) is an inclusive project that is pregnant to profound changes for International Political Economy but also for Chinese Political Economy. In $21^{\text {st }}$ Century, when Chinese Political Economy is observed, it is to be seen that engines of the economy that once led China to development become the very problems that are distorting the development and growth today. Those problems make the "challenges of China" and they are deeply connected to each other making local operations ineffective in long term solutions. Hence, China is in need of a restructuring in social and economic architecture of the country that will not only enable a grand solution to those challenges but that will also guarantee the stability in domestic affairs. By employing One Belt One Road Initiative, China aims to achieve peace and harmony in her domestic structures regarding economy and society. Therefore, China's domestic challenges render One Belt One Road Initiative essential for the survival of a stable China.
\end{abstract}

\section{Keywords}

One Belt One Road Initiative, Chinese Political Economy, China's

Development, Domestic Challenge

\section{Introduction}

Cold War has shaped the International Relations in a way that bipolar world politics has started to be accepted as given. Any rising power in the international arena has been interpreted as either consolidator or a challenge to American dominated status quo (Chuntao, 2014) [1]. For that reason, China's rise in international political economy has given way to a number of interpretations in which "China Threat" theories gathered lots of supporters (Huntington, 1997: p. 207) [2]. In that regard, with Xi Jinping's annunciation of "New Silk Road" and 
" $21^{\text {st }}$ Century Maritime Silk Road" projects—-which will be hereafter referred as Belt and Road or One Belt One Road Initiative-in 2013, international community has started to discuss the implications of the Belt and Road Initiative not only for the international political economy but also for the world politics. Even rising apprehension in International Relations gave rise to theories that assimilated One Belt One Road Initiative to China's Marshall Plan. Hence, having learned from Second World War and Cold War, China's new Initiative was predicted to be a first step towards the establishment of a hegemonic bloc (Banarjee, 2016) [3].

Concerns regarding the China's intentions and the future of international political economy and world politics are not unearthly. Yet, significations of China's power in world politics are not fully discovered. What can be explored is to note that coming to a conclusion from the deduction of the history that interprets any rising power to be a challenge or threat to status quo is accepting a "historic ceteris paribus" in world political history. Examples in our history are the maps towards the comprehension of today, but it is to be analyzed carefully if the conditions today are the reflecting the prior circumstances. In that regard, it is to admit that since the end of Cold War world has changed greatly. There are new actors, and International Relations are hardly guided by a bipolar world order but from a multipolar order. In this order, China is a power that can hardly be judged by prior examples in the world. Not only because of ever changing the political and economic environment since the end of Cold War, but also because of difficulty of arriving at a conclusion that China is driven by the same interests with the countries that were given before her as example. Hence, to understand this phenomenon-as well as the motivation behind the foundation of One Belt One Road Initiative-it is critical to analyze China from her domestic dynamics. An analysis of China's internal circumstances on economy, politics and society will reveal the priorities of China in her both domestic and foreign affairs.

An overview of the modern Chinese economy will affirm that towards the end of the 20th century, China has outpaced every other country in the world by catching the hypergrowth and becoming the world's second biggest economy only in a period of 30 years (Yulu, 2014: pp. 1-16) [4] (Figure 1). As Dixin (Dixin, 1982: pp. 1-27) [5] stressed With Deng Xiaoping's adaptation of market oriented policies China has experienced a great boom in his economy by employing potential economic forces in use. As the Deng Xiaoping era in Chinese economic history started, great share of population able to form the workforce, cheap labor and cheap resources along with the policies that reduced the transactional costs have enabled the Chinese economy to take off very fast. However, after almost forty years even though Chinese economy has caught the hypergrowth, the engines that triggered the fast development started to challenge the sustainability and stability of economic development as well as the future of a just and harmonious society (Geis \& Bolt, 2009) [6].

Today, Chinese economy and society are challenged with a number of problems 


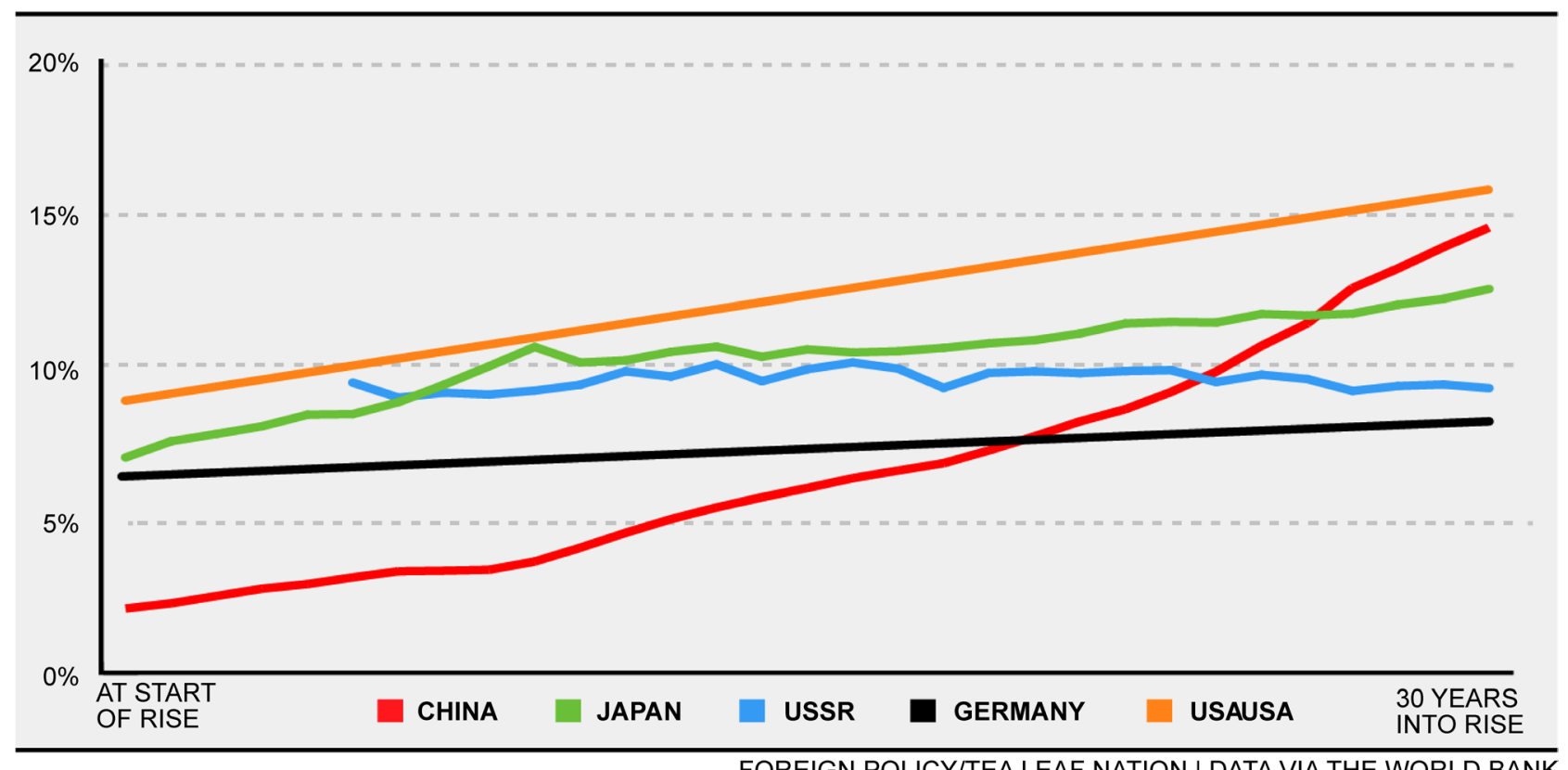

Figure 1. Share of global GDP over thirty year period (Foreign policy, 2014) [7].

that rooted in the economic factors that were once built on purpose to accelerate the development of the country. In that regard, as de Lisle and Goldstein (de Lisle \& Goldstein, 2015: pp. 16-18) [8] claims huge gap among classes, uneven development in different regions, unsustainability of current economic model, environmental problems and increasing energy demand have started to push Beijing to adopt a new strategy not only to keep a sustainable economic environment but also to achieve a harmonious society that is not threatened by the rising tensions of economy (de Lisle \& Goldstein, 2015: pp. 1-18) [8].

In this work, it is seen that those challenges that are threatening the stability of China with regards to economy and society, are interdependent and interconnected. Therefore, a step by step methodology would remain ineffective by failing to create a long term solution. However, with One Belt One Road Initiative, China will be able to transit its economy and society by using it as a grand tool that will affect every sphere of the problems. Hence, this work claims One Belt One Road to be not only a project that is solely pregnant to implementations on international politics and economy but also containing factors that are essential to survival of a stable and healthy environment in domestic economy and society. One Belt One Road Initiative is seen as an Initiative that looks out for the China's internal problems, rather than the matters regarding foreign policy. For this reason, even though One Belt One Road Initiative's possible effects on world politics and international political economy are also elaborated on, main focus will be on the contemporary challenges ahead of China. By comprehending the China's challenges in the $21^{\text {st }}$ century, it is called that One Belt One Road Initiative's essential roles will be better understood; One Belt One Road Initiative is a fixer for China's domestic challenges.

A true analysis of every challenge that China is claimed to experience in this 
work, as well as the benefits of One Belt One Road Initiative necessitates a deep research in every point that is mentioned and to be mentioned. Likewise, nature of the topic necessitates focus of this research to be not limited to a few data but to subjects of a vast field. In that regard, in order to band together a vast data to test hypothesis it is significantly necessary to benefit from the researches made heretofore. Hence, this research is based on creating a network among the findings of the scholars as well as the reports that are published by the institutes under a framework that is based on the indicators of Chinese Political Economy. Employing the academic literature and research results in different fields, outcomes are summarized and categorized under two sets of tables within their respective cases. Later, over the comparison of these tables it is targeted to test the points claimed in this work.

In order to examine the challenges ahead of China and how those challenges are linked to One Belt One Road Initiative, three more chapters are designed. Firstly, China's current political economic circumstances will be explored. As the world's third largest country by area, China's political, economic and societal conditions differ greatly with respect to different regions. While some regions developed greatly, some are still less developed or relatively undeveloped. Although economic and political policies are implemented on the country level, their reflections to different regions and parts of society differed greatly as certain regions and provinces enjoy features such as access to market, resources, etc. that others don't. Furthermore, in order to rush up the development, some cities were given priority in development while those that were ostracized from such priority were tasked to support the development through different means. Over the years these roles that were assigned to different cities created a gap in the country among different regions not only on the economic level but also on the society (Chuntao, 2014: pp. 107-109) [1]. Furthermore, it has affected the country's future in coming years. Thus, it is to put that conditions that enabled hyper growth are in the core of structural problems China is experiencing today. Only after the political economic circumstances grasping China are detailed those challenges will be categorized in order to trace the evaluation of the problems which will enable a correlation between One Belt One Road and China's political economic details.

Secondly, One Belt One Road Initiative will be separately analyzed. As it is seen uttermost important to understand One Belt One Road Initiative as not only on an international ground but also on domestic level with significant outcomes. Through that analysis, OBOR's foreseeable effects will be revealed with regards to China's domestic economic and social structures. Furthermore, it is objected to chart the domestic outcomes of those affects OBOR's analysis will reveal. Therefore, One Belt One Road Initiative's domestic outcomes for China will be mapped in favor of an easier comparison that will follow.

Before concluding this paper, results schematized in second and third chapter will be concluded in order to prove the point claimed earlier. It is planned to compare categorizes that are formed by the challenges of China and positive 
domestic outcomes that are foreseen to be created by the successful implementation of One Belt One Road. By such comparison it will be evaluated if the problems that are forged by political and economic policies since the implementation of reforms can be resolved in $21^{\text {st }}$ century's China by the Initiative as it is being claimed.

\section{Development of China and What Are the Challenges She Is Facing Today}

After the foundation of People's Republic of China what was left for the Mao Zedong leadership was very little industry, small market and a vast country with millions of people living in poverty. However, after the Cultural Revolution what were left for the Deng Xiao Ping government were almost same conditions with the prior government only with a slight difference; a comprehension of the inadequacy of the policies that was held earlier. Therefore, Xiao Ping government came with significant reforms in economic policies; Deng Xiao Ping wanted to reserve the country with its all idealism except adopting different policies to boost the economy (Dixin, 1982: pp. 26-29) [5]. By "letting the some people getting richer before the others" China slowly took off to "cross the river while feeling the stones under her feet" (Li \& Li, 1997) [9]. Deng Xiao Ping emphasized Mao Zedong and Communist Party of China to be sole fathers of the Chinese administration. Yet, understanding the political economy Xiao Ping tried to utilize the China's resources by adopting policies of market economy and opening up. With the change in policy, according to Suinian (Suinian, 1982: pp. 28-51) [10] resources that China contained have become her advantages in international political economy rather than a drawback that was experienced heavily during the implementation of Second Five Year Development Plan and Cultural Revolution. It is not incorrect to comment that those policies that were taken during the Deng Xiao Ping era have not changed in the core greatly over the following leaderships (Breslin, 2010: pp. 52-62) [11]. Hence, the conditions that were inherited in 1978 to today are the backbones of the problems that China is going through now.

Looking at the economic policies adopted at that time (in Deng Xiao Ping era) it is to see that utilization of the existing resources to advance the development become the center of economic policies. As those resources were mostly composed of abundant fossil energy resources, tremendous labour force and a vast coastal line, China was shaped by them in the following thirty years not only in the economic sphere but also in her societal and political structures. Via different means such as State Owned Enterprises (SOE) and incentives industrialization was boosted greatly. In that regard, Eastern China was designated as trade hub for its convenience of maritime trade routes; whereas, Western and Central China provided the work force and energy resources mainly.

It is to be noted that observation of the fast track development contemporary China can prove the policies taken in the opening up era successful, but it is also for sure that they have created a number of complications. To start with, with 
the continuing emphasize on industrialization, heavy industrialization has become the motor of the growth. In that regard Yulu argues, even though after China's membership to World Trade Organization in 2000 the share of net exports in the economy has greatly increased, investment is still highest in the world - \%48 percent (The Guardian, 2014) [12]. With little share on domestic consumption, Chinese economy is heavily depended on investments and net exports that are conditioned on industrial capacity. Secondly, with the priority of development given to Eastern cities, mostly by special economic zones, Western cities couldn't develop as fast as the Eastern China. As the northern China Heilong Jiang, Jilin, Inner Mongolia, Liaoning as well as Xinjiang - were full of fossil energy resources such as coal and natural gas, they couldn't develop since their main function for the Chinese economy was mainly based on energy production which was hardly more than setting mines and factories (Business Week, 2013) [13]. Likewise, similar to Northern provinces, Central China also remained relatively less developed as cities in this region depended on industrial and agricultural production (Huang, 2015: pp. 84) [14]. So in whole China, development was correlated to the attraction of business and cost of the business done in the city. With fewer wages and less attraction to businesses, Western and Center Provinces have either remained undeveloped or become less developed compared to Easter Provinces (Cooper, 2008, p. 4) [15]. Finally, in order to ensure the continuation of high growth rates for the following decades since the opening up era, China guaranteed cheap labor and abundant work force available to market by taking different social policies in action such as the "Hukou" household registration. Household registration system partially prevented a big migrant population that migrated to Eastern, more developed cities, by putting serious drawbacks ahead of them in different spheres such as education and health services if they moved to another city without registration (Huang, 2015) [14]. As a result, not only Hukou partially prevented a migrant population emerging in a greater numbers, but also it continued to destabilize the population in the less developed regions which in return compelled them to lower life standards (Liang, 2015: pp. 42-45) [16].

With all of her imbalances, China continued to develop vastly over the last few decades. Yet, with changes in economic and societal level such as changing demographic levels and rising middle class, prior structures created due to uneven economic policies are far away from providing a safe environment in presentday China. On the contrary they are threatening the future of a developed existence of the country.

As it can be seen from Table 1, China is challenged in various ways today (Row C, representing "Challenges"). Challenges in front of China are categorized under "Imbalance in Industrial Structure", "Environmental Problems", "Inequality Among Regions", Income Inequality", "Low Domestic Consumption Rates", "Lack of Jobs for White Collar Workers", "Unsustainable Economic Development". Although those problems are categorized differently, it is to note that they are interrelated as they are composed of shared factors (Column F, 
Table 1. F: Factors. C: Challenges.

\begin{tabular}{|c|c|c|c|c|c|c|c|}
\hline $\mathrm{F}$ & $\begin{array}{l}\text { Imbalance } \\
\text { in Industrial } \\
\text { Structure }\end{array}$ & $\begin{array}{c}\text { Environmental } \\
\text { Problems }\end{array}$ & $\begin{array}{c}\text { Inequality } \\
\text { Among } \\
\text { Regions }\end{array}$ & $\begin{array}{l}\text { Income } \\
\text { Inequality }\end{array}$ & $\begin{array}{c}\text { Low Domestic } \\
\text { Consumption } \\
\text { Rates }\end{array}$ & $\begin{array}{l}\text { Lack of Jobs } \\
\text { for White } \\
\text { Collar Workers }\end{array}$ & $\begin{array}{c}\text { Unsustainable } \\
\text { Economic } \\
\text { Model }\end{array}$ \\
\hline Heavy Industralization & $\mathrm{X}$ & $\mathrm{X}$ & $\mathrm{X}$ & $\mathrm{X}$ & & $\mathrm{X}$ & $\mathrm{X}$ \\
\hline $\begin{array}{l}\text { Prior Development of } \\
\text { Coastal Regions }\end{array}$ & & $\mathrm{X}$ & $\mathrm{X}$ & $\mathrm{X}$ & $\mathrm{X}$ & $\mathrm{X}$ & $\mathrm{X}$ \\
\hline Cheap Labor Force & & & $\mathrm{X}$ & $\mathrm{X}$ & $\mathrm{X}$ & $\mathrm{X}$ & $\mathrm{X}$ \\
\hline $\begin{array}{l}\text { Great Share of Workforce } \\
\text { in Population }\end{array}$ & $\mathrm{X}$ & & & & & $\mathrm{X}$ & $\mathrm{X}$ \\
\hline $\begin{array}{l}\text { Unbalanced Market } \\
\text { Oriented Policies }\end{array}$ & $\mathrm{X}$ & $\mathrm{X}$ & $\mathrm{X}$ & $\mathrm{X}$ & $\mathrm{X}$ & $\mathrm{X}$ & $\mathrm{X}$ \\
\hline $\begin{array}{l}\text { Dependency on } \\
\text { Fossil Energy }\end{array}$ & $\mathrm{X}$ & $\mathrm{X}$ & $\mathrm{X}$ & $\mathrm{X}$ & & $\mathrm{X}$ & $\mathrm{X}$ \\
\hline Excessive Investment Rates & $\mathrm{X}$ & $\mathrm{X}$ & $\mathrm{X}$ & $\mathrm{X}$ & $\mathrm{X}$ & $\mathrm{X}$ & $\mathrm{X}$ \\
\hline
\end{tabular}

representing "Factors". Yet, an elaboration will make it clearer where they are distinct and related.

"Imbalance in Industrial Structure" indicates to the industry's crooked structure. Even though industrialization took of very fast and spread to all country it has happened in under planned economy (Barry, 2015) [17]; China wanted to increase her export and investment share by focusing on cheap cost productions. Primary Industry developed very little and was followed by Tertiary Industry with a higher outcome. Yet, contrary to Primary and Tertiary Industry, Secondary Industry occupied almost all of the industrial production, resulting in China to be a vast factory manufacturing all kinds of products for the entire world. Furthermore, besides the growing Industrialization, agricultural industry remained dwarf-modernization in agricultural was disregarded-compelling the traditional agricultural production methods to be used which in return created a problem of agricultural production (Razmi, 2008) [18]. As a result, although land and human capital is used highly, agricultural production is far enough from supplying the demand needed in China. Secondly, "Environmental Problems" include problems caused by uncontrolled industrialization and insensible development; desertification, pollution, deforestation, water resources and climate change makes the biggest problems China faces in terms of environmental problems not only as a threat to public health but also as an erosion to economic gains (Eichengreen, Whyplosz, Park, 2014: pp. 148-149) [19]. "Inequality among regions", are mainly composed of uneven development among regions as it is the case between Western-Central Provinces and Eastern Provinces. Not only provinces in Western and Central China are less developed but also they bear lower life standards and enjoy fewer rights compared to eastern provinces. "Income Inequality" refers to the gap between the rich and poor. Even though China has lifted more than 500 million people over 30 years, there are still more than 40 million people living on less than a dollar per day. Likewise, as it China's 
GINI Index (The World Bank GINI INDEX, 2016) [20] has shown, a very small fraction of the population has gained a very big part in overall income pool compared to the small share the rest of the population has. Next, when China's economic development structure is analyzed, it is to be seen that while ration of investment and export are very high there is "Low Domestic Consumption Rate". Chinese economy is driven by investments and exports which makes economy externally dependent and unsustainable in the long run. On the other hand, "Lack of Jobs for White Collar Workers" indicates to a more social problem than others. During the development, factories and constructions chiefly demanded unskilled workers; however, different from early reform era, Chinese demography has changed greatly. Now, Chinese population is more educated and proportion of the population that is able to join the work force is decreasing. Hence, if the current economic structure continues China will fail to meet the level of workforce she domestically needs. Similarly, she will also fail to provide the jobs that will meet the education level of labor force as well. Finally, different than other categories "Unsustainable Development" is addresses the all categories. It can be put that, unsustainable development is the general description of the Chinese economy today (Schellekens, 2013) [21]. In order to catch hyper growth, Beijing has employed policies that have focused on more short term implications. As a result, while China and international economy as well as world politics changed greatly; ongoing economic structures are far away from keeping up the development in the long run providing a promising future for Chinese people.

\section{OBOR and Its Implications on China Domestically}

For more than 2000 years, Ancient Silk Road has enabled the trade between East and West bringing different nations together and resulting in not only commercial activities but also cultural, political and social exchange. Learning from the Ancient Silk Road, China in $21^{\text {st }}$ Century has acknowledged the profits of trade and importance of a corridor between the European Trade Hub and East Asian Trade Hub (State Council of PRC, 2015) [22]. Furthermore, China has comprehended not only the significance of such corridor on her foreign policy and foreign economic relations but also in her domestic matters as well.

Today, facing a number of challenges on domestic and foreign affairs China is lacking a grand tool that will be affective on all levels as it was emphasized. In that regard, on the domestic level China faces the defects of over industrialization, social gaps, changing demographics and so on. As it comes to the solution, due to nature of problems (interconnectivity of problems that was analyzed in previous chapter), China needs One Belt One Road Initiative to restructure her economic forces while enable her to reform the economic and societal spheres that will result in the reconstruction of development and growth.

If One Belt One Road Initiative is regarded, a number of uses of the Initiative become apparent for China. To start with, through OBOR transactional costs will be reduced both inside and outside of China. As claimed by Qiren (Qiren, 
2013) [24] for China to increase her development without going through an expansion in industrialization-by number of factories and number of production - China can gain simply by reducing transactional costs. Secondly, as it is regarded that China is heavily depended coal, petroleum and natural gas resources are utterly important in responding to growing hunger of industry in the country. Through One Belt One Road Initiative, China will not only be able to reach to the resources in Middle East and Central Asia but by the Belt and Road Initiative she will be able to secure their continuation and availability in the international market (Simpfendorfer, 2009: pp. 28-31) [25]. Next, Initiative is to contribute and incite the development of central and western regions. As it can be seen from the Figure 2, Belt and Road's main destinations inside the China are Yiwu, Xian, Chongqing and Urumqi. Becoming a center of trade, those cities are likely to be followed by increased development as they will be more attractive to businesses and collect investments. Likewise, these cities will be given priority in development by the central government in order to quicken the progress (BOCOM International, 2015) [23]. Similar to development of disadvantaged regions, urbanization will also be boosted. By developing the Western and Central China, rural population will gradually decrease in order to benefit from the increasing wages and life standards that are to come with the development in cities. Similarly, given the socio economic problems such as Hukou registration, migrant population in the East is to be reduced in this way creating farther solutions to overcrowding, wage cuts, and employment (Geis \& Holt, 2009) [6]. Another effect that OBOR is expected to have is the employment opportunities for white and blue collar workers in China. As Initiative is kick started, there are a number of fields needed to be cleared such as construction of railways and administration of the Initiative on both local and regional level. As OBOR includes a great number of countries on its route-and as the China is the master builder of OBOR in undeveloped countries-both inside and outside of China

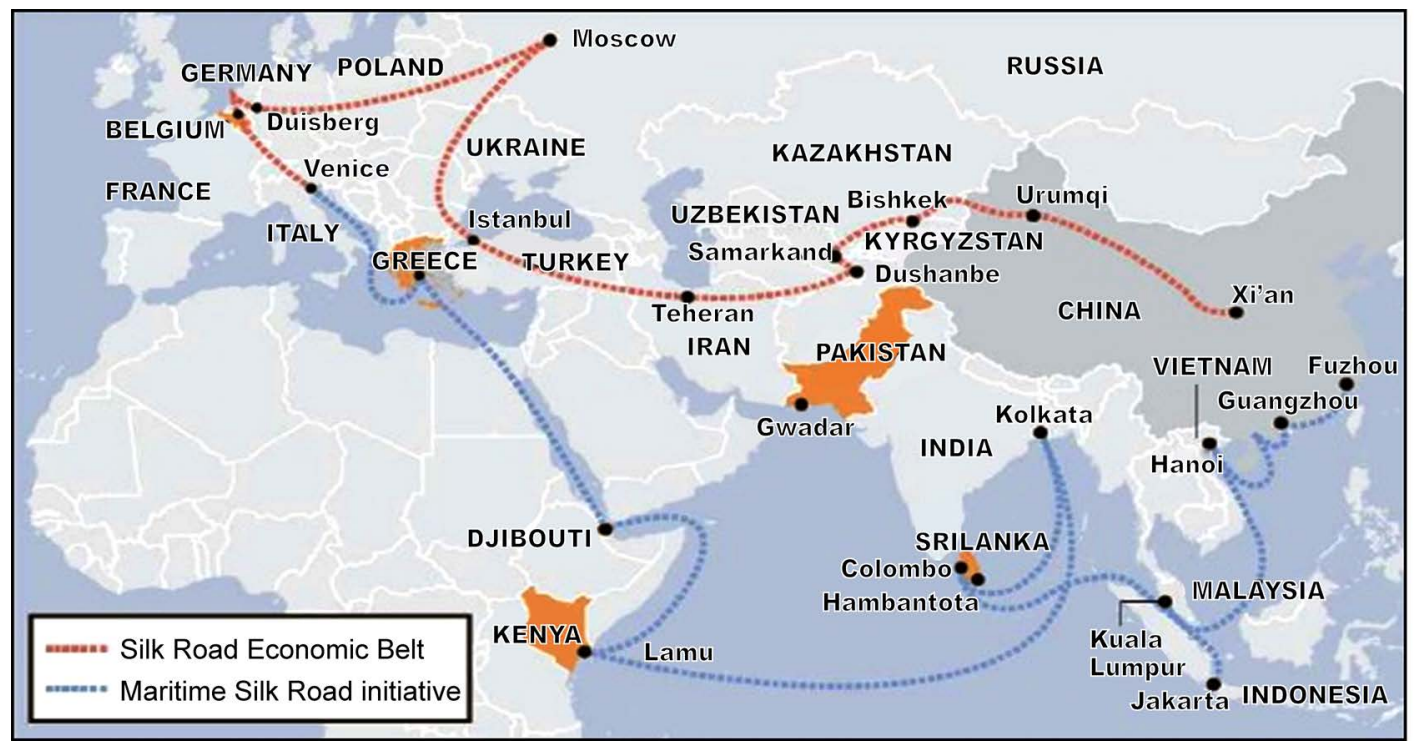

Figure 2. Planned trade routes in OBOR (BOCOM international, 2015) [23]. 
job vacancies are to be created for unskilled and skilled workers along with the executive level professionals. Also indirectly, shifting from mindless, petty, cronycapitalist to a more conscious industrialization plan China will need more skilled workers and white collars in the future (Xinhua, 2015) [26]. Next but not last, through Belt and Road Initiative Chinese exports will increase. Even though China has already been trade partners with a number of countries and organizations (and Chinese exports are already very high), Chinese exports are likely to increase as a result of the development that neighbors of China and other undeveloped countries will bear with. Chinese exports are predicted to merger with the stimulation of development. Finally, another possible influence of OBOR on and in China is its railroading to transparency. If China is to initiate an international project and create international partnerships, she has to make transparency a principle in domestic policies and politics. In order to execute the different relationships, that are especially with regards to economic relationships, Chinese administration has to implement transparency not only in the fields where globalization are required but also in her own domestic affairs no matter business related or not.

A number of areas One Belt One Road assumed to have a significant effect on can be categorized as following: reduction of transactional costs, securitization of energy resources, development of central and western regions, increasing urbanization, employment opportunities for white collar and blue collar workers, promotion of export and transparency. When the route of OBOR is analyzed (Figure 2), it will be revealed that OBOR is taking off from Xian and passing through Urumchi to Alatow Pass to Kazakhstan. While Maritime Silk Road is designed to have effect on maritime trade, land route will not only enable the commercial activities but also it will boost the urbanization and development of the cities that are on its route. In that regard it is not wrong to put that, New Silk Road has two essential features in its core that are leading to other benefits of the project, that are respectively development of station cities and transportation linkage. Development of the Western and Central Regions, that had experienced very low rates of development over the years if compared to East, is going to break the bottle neck in the country that were leading to greater problems. Likewise, a network of land routes will make it possible for those cities to engage in trade easier and cheaper.

Starting from those two main points, as noted earlier, in this work main effects of the OBOR Initiative are defined as reduction of transactional costs, securitization of energy resources, development of central and western regions, increasing urbanization, employment opportunities for white collar and blue collar workers, promotion of exports and finally transparency. Those fields that OBOR is foreseen to affect in the country's socioeconomic structures are assumed to result in a balanced economic model, sustainable economic development, increased incomes, domestic consumption and reduction of environmental problems. Correlation between the effects of the One Belt One Road Initiative and the assumed results of those components on country's socioeconomic structure is shown on Table 2 . 
Table 2. I: Implications. R: Results.

\begin{tabular}{|c|c|c|c|c|c|}
\hline $\mathrm{R}$ & $\begin{array}{l}\text { Sustainable Economic } \\
\text { Development }\end{array}$ & $\begin{array}{l}\text { Increased } \\
\text { Incomes }\end{array}$ & $\begin{array}{c}\text { Domestic } \\
\text { Consumption }\end{array}$ & $\begin{array}{c}\text { Reduction of } \\
\text { Environmental Problems }\end{array}$ & $\begin{array}{c}\text { Balanced } \\
\text { Economic Model }\end{array}$ \\
\hline Reduction of Transactional Costs & $\mathrm{X}$ & & & & $\mathrm{X}$ \\
\hline Securitization of Energy Resources & $\mathrm{X}$ & $\mathrm{X}$ & & $\mathrm{X}$ & $\mathrm{X}$ \\
\hline $\begin{array}{l}\text { Development of Central and } \\
\text { Western Regions }\end{array}$ & $\mathrm{X}$ & $\mathrm{X}$ & $\mathrm{X}$ & & $\mathrm{X}$ \\
\hline Increased Urbanization & $\mathrm{X}$ & $\mathrm{X}$ & $\mathrm{X}$ & $\mathrm{X}$ & $\mathrm{X}$ \\
\hline $\begin{array}{l}\text { Employment Opportunities for } \\
\text { White and Blue Collar Workers }\end{array}$ & $\mathrm{X}$ & $\mathrm{X}$ & $\mathrm{X}$ & & $\mathrm{X}$ \\
\hline Promotion of Exports & $\mathrm{X}$ & $\mathrm{X}$ & & & $\mathrm{X}$ \\
\hline Transparency & & & & & $X$ \\
\hline
\end{tabular}

\section{Conclusion: OBOR and Its Implications on China's Challenges}

Today, China is still a strong economy entity and it is continuing to develop. Chinese administration has more responsibility in world affairs, Chinese economy is one of the strongest windbags of global economy and Chinese population is growing not only in numbers but also in quality of skills. In the big picture what is seen is a developing China dressing herself up with technology and knowledge. Yet, as Chinese development is based on her utilization of the economic capitals, such as work force, vast energy resources and access to different markets; it is not before long China loses the advantages she possesses in contemporary global economy. Because, not only environment of international is changing but also China will be short in the capitals she has now-work force, energy resources and markets in the long run. A sustainable and stable development necessitates China to utilize the resources she has now which in return renders a structural change in the policies economy follows. In that regard, what is left for the Beijing is to respond to the bottle necks of a healthy climate in the country that will guarantee safer development plans and will avoid huge costs in society.

As it was discussed in chapter II, there are a number of issues that hint the Chinese economy and society. Those issues result in imbalance in industrial structure, environmental problems, inequality among regions, income inequality, low domestic consumption rates, lack of jobs and unsustainable economic model. It was discussed that step by step solutions or handling each challenge in itself will prove ineffective in the long run as the root of the challenges is not dependent on a sole factor but to a number of factors. In that regard, if a challenge is analyzed and a set of solutions would be found, their reflections in other categories will not be foreseen and/or measured accurately. For example, if the goal is to increase incomes in order to a decrease inequality, heavy industrialization, prior development of coastal regions, cheap labor force, unbalanced market oriented policies, dependency on fossil energy, and excessive investment rates 
are all needed to be operated on. However, in this case it will not be calculated accurately as the great share of work force in population is neglected. As a result, linkage among the challenges makes it mandatory to implement a solution that will be effective in every category.

A quest for a project that will be effective on every level of challenge China faces leads to One Belt One Road Initiative. When the results of the Initiative, Table 2, Row R, are examined, it is to see that results are matching with the Challenges that presented in Table 1, Row C. In that regard, even though the Factors leading to the challenges China faces now vary, results of the One Belt One Road Initiative on China affects every challenge directly and indirectly. Moreover, besides the points mentioned, One Belt One Road Initiative is also to affect China domestically not only through the direct Implementations it has on Chinese economy and society but also with gains in international economy and politics. Likewise, relief of tensions in economy and society will bring along stability in politics as well.

To conclude, it is without a doubt that One Belt One Road Initiative is not a simple project or institution. It will tag along a number of changes in world politics and global economy. Those changes in the international arena are not defined as there are multiple actors and institutions. Furthermore, China's interests are not defined when it comes to world politics and global political economy. However, the task of defining OBOR can be concluded by the interests of China in her domestic politics. An attentive research on the obstacles ahead of a healthy and peaceful China necessitates her to go through a detailed change in the structure of policies she used to incite hypergrowth. Yet, as it was discussed in this piece of work, for China to achieve such objects it is crucial for her to implement Belt and Road. It is not known what the Initiative has for the world; nevertheless from the perspective of China, One Belt One Road Initiative creates solutions that are essential for the continuity of stability.

\section{References}

[1] Xie, C.T. (Ed.) (2014) Challenges for China: How the CPC Makes Progress. New World Press, Beijing.

[2] Huntington, S.P. (1995) The Clash of Civilizations. Simon \& Schuster, London.

[3] Banerjee, D. (2016) China's One Belt One Road Initiative-An Indian Perspective, Perspective, No. 14.

[4] Chen, Y.L. (2014) Chinese Currency and the Global Economy: The Rise of the Renminbi. McGraw Hill, USA.

[5] Xu, D.X. (1982) China's Search for Economic Growth: The Chinese Economy Since 1949. The New World Press, Beijing.

[6] Geis, J. and Holt, B. (2009) Harmonious Society: Rise of the New China. Strategic Studies Quarterly, 3, 4.

[7] Foreign Policy (2016) Tea Leaf National Charts. http://foreignpolicy.com/channel/tea-leaf-nation/

[8] de Lisle, J. and Goldstein, A. (Eds.) (2015) China's Challenges. University of Pennsylvania Press, Philadelphia. 
[9] Li, D. and Li, S. (1997) The Chinese Economy After Deng. The Journal of the International Institute, 4, 3. http://hdl.handle.net/2027/spo.4750978.0004.307

[10] Liu, S.N. (1982) Economic Planning. In: Xu, D.X., Ed., China's Search for Economic Growth: The Chinese Economy since 1949, The New World Press, Beijing, 28-51.

[11] Breslin, S. (2010) China's Emerging Global Role: Dissatisfied Responsible Great Power. Political Studies Association, 30, 52-62. https://doi.org/10.1111/j.1467-9256.2010.01385.x

[12] The Guardian (2014) China GDP: How It Has Changed Since 1980s. https://www.theguardian.com/news/datablog/2012/mar/23/china-gdp-since-1980

[13] Business Week (2013) On China's Electricity Grid: East Needs West-For Coal. http://www.businessweek.com/articles/2013-03-21/on-chinas-electricity-grid-east-n eeds-west-for-coal

[14] Huang, Y. (2015) Policy Model and Inequality. In: de Lisle, J. and Goldstein, A., Eds., China's Challenges, University of Pennsylvania Press, Philadelphia, 83-105.

[15] Cooper, R.N. (2008) China's Coming Demand for Energy. In: Eichengreen, B., Whyplosz, C. and Park, Y., Eds., China, Asia, and the New World Economy, Oxford University Press, Oxford, 1-18. https://doi.org/10.1093/acprof:oso/9780199235889.003.0001

[16] Liang, Z. (2015) Migration, Hukou and the Prospects of an Integrated Chinese Society. In: de Lisle, J. and Goldstein, A., Eds., China's Challenges, University of Pennsylvania Press, Philadelphia, 42-60. https://doi.org/10.9783/9780812291766-003

[17] Naughton, B. (2015) Economic Rebalancing. In: de Lisle, J. and Goldstein, A., Eds., China's Challenges, University of Pennsylvania Press, Philadelphia, 105-125. https://doi.org/10.9783/9780812291766-006

[18] Razmi, A. (2008) Is the Chinese Investment- and Export-Led Growth Model Sustainable? Some Rising Concerns. Economics Department Working Paper Series, University of Massachusettes, Amherst.

http://scholarworks.umass.edu/econ workingpaper/22

[19] Eichengreen, B., Whyplosz, C. and Park, Y. (2008) China, Asia, and the New World Economy. Oxford University Press, Oxford. https://doi.org/10.1093/acprof:oso/9780199235889.001.0001

[20] The World Bank (2016) Gini Index. http://data.worldbank.org/indicator/SI.POV.GINI?end=2012\&locations=CN\&name desc $=$ true\&start $=2012 \&$ view $=$ map

[21] Schellekens, P. (2013) A Changing China: Implications for Developing Countries. Poverty Reduction and Economic Management Network, No. 118.

[22] State Council of the People's Republic of China (2015) Silk Road Fund's 1st Investment Makes China's Words into Practice. http://english.gov.cn/news/top news/2015/04/21/content 281475093213830.htm

[23] BOCOM International (2015) One Belt One Road Initiative.

[24] Zhou, Q.R. (2013) Foundation for China's Economic Growth. Procedia-Social and Behavioral Sciences, 72, 20-26. https://doi.org/10.1016/j.sbspro.2013.03.058

[25] Simpfendorfer, B. (2009)The New Silk Road: How a Rising Arab World İs Turning Away from the West and Rediscovering China. Palgrave and Macmillian, Hampshire. https://doi.org/10.1057/9780230233652

[26] Xinhua News (2015) “One Belt, One Road” Initiative Offers Opportunities for Eurasia: Chinese Scholar.

http://news.xinhuanet.com/english/2015-03/24/c 134092811.htm 
Submit or recommend next manuscript to SCIRP and we will provide best service for you:

Accepting pre-submission inquiries through Email, Facebook, LinkedIn, Twitter, etc. A wide selection of journals (inclusive of 9 subjects, more than 200 journals)

Providing 24-hour high-quality service

User-friendly online submission system

Fair and swift peer-review system

Efficient typesetting and proofreading procedure

Display of the result of downloads and visits, as well as the number of cited articles Maximum dissemination of your research work

Submit your manuscript at: http://papersubmission.scirp.org/

Or contact jss@scirp.org 